\title{
Relationship between Obesity and Blood Uric Acid Levels in Patients with Hyperuricemia at Bangli General Hospital
}

\author{
Putu Pradnya Saraswati ${ }^{1}$, Sagung Putri Permana Lestari Murdhana Putere ${ }^{1^{*}}$ \\ ${ }^{1}$ Faculty of Medicine and Health Sciences, Universitas Warmadewa, Denpasar, Bali \\ *putrip184@gmail.com
}

\begin{abstract}
Hyperuricemia is a condition in which there is an increase in blood uric acid level above normal. Some studies have shown more than $70 \%$ of hyperuricemia sufferers are obese and have a family history of hyperuricemia. This study aimed to determine the relationship between obesity and family history and blood uric acid levels in patients aged above 30 years with hyperuricemia at Bangli General Hospital, Bali, Indonesia. This study was an analytic study with cross-sectional design. The study samples were 77 people selected by simple random sampling. Secondary data was taken from the patients' medical records at Bangli General Hospital. Levels of blood uric acid were measured using auto check GCU, obesity was measured based on body mass index using microtoise tools to measure height and weight, while family history was obtained by interviews. The data were analyzed using bivariate analysis with Chi-square test $(\alpha=0,05)$. Results of obesity measurement showed that more of the study subjects had obesity ( 49 persons or $63,6 \%$ ) and more (46 persons or 59,7\%) had family history. The study results showed that there was no relation between obesity and blood uric acid level $(\mathrm{p}=0,060)$ while there was relation between family history and blood uric acid level $(\mathrm{p}=0,006)$.
\end{abstract}

Keyword: Relatonship, Blood Uric Acid, General Hospital.

\section{Introduction}

Uric acid is the end product of purine metabolism which can originate from metabolism in the body (endogenous factors) and outside the body such as food (exogenous factors). Generally uric acid levels in adult men is $\geq 7.5 \mathrm{mg} / \mathrm{dl}$, elderly men $>40$ years old of $\geq 8,5 \mathrm{mg}$ / dl, adult women $\geq 6,5 \mathrm{mg} / \mathrm{dl}$ and elderly women $>40$ years old of $\geq 8 \mathrm{mg} / \mathrm{dl}$, so uric acid levels in men are higher than women. If there is an increase in uric acid levels above normal, it will cause interference with the joints accompanied by pain. This is due to the buildup of crystals due to high levels of uric acid in the blood. This disease is often referred to as gout arthritis known in the community as uric acid.[1]

Hyperuricemia can be caused by three factors, namely primary factors, secondary factors and predisposing factors. The primary factor is influenced by genetic factors. Secondary factors can be caused by two things, they are excessive production of uric acid and decreased excretion of uric acid, in addition it can also coexists with other diseases such as obesity, diabetes mellitus and hypertension. Predisposing factors are influenced by age, sex and excessive purine intake [2]. Based on data from RISKESDAS (2013), the prevalence of arthritis in Indonesia was diagnosed at $11.9 \%$ and based on symptoms of $24.7 \%$. The prevalence of arthritis in Bali based on diagnosis is in the highest number, which is $19.3 \%$ and 
based on the symptoms is in the third place, $30 \%$. The prevalence of arthritis increases with age, with the highest prevalence at $\geq 75$ years and types of arthritis that are often experienced by the elderly, there are gout arthritis, osteoarthritis and rheumatoid arthritis. [3]

Some studies show that hyperuricemia patients are obese, one of which is a study conducted by Listri in 2014 in Daleman Gadingharjo, Sanden Bantul, showing that there is a relationship between obesity and hyperuricemia, and several studies explain family history as influencing the occurrence of hyperuricemia as found through a study by Cindy in 2015 at Paniki Bawah Health Center, Mapanget District, Manado. The results of this study explain that there is a relationship between family history with hyperuricemia. [4,5] Several studies conducted in Denpasar Bali reported a prevalence of hyperuricemia of 18.2\%.6 From the data reported in 2015, the number of arthritis cases in Bangli Regency was 1,004. Based on the patient's medical record data from January to November 2016 in Bangli Hospital there were $32 \%$ of hyperuricemic patients.

Based on the results of several previous studies regarding the relationship of obesity and a history of hyperuricemia in families, this study was conducted to determine whether there is a relationship between obesity and family history of blood uric acid levels in patients with hyperuricemia over 30 years of age at Bangli General Hospital.

\section{Method}

\subsection{Sample Collection}

This research was conducted at Bangli General Hospital, Bangli Regency, Bali Province. This study is an analytical study that used a cross-sectional research approach to determine the relationship between obesity and family history with uric acid levels in patients with hyperuricemia aged over 30 years in Bangli General Hospital. The data used are secondary data taken from the patient's medical record, as well as direct measurements of uric acid levels, BMI and direct interviews to find out the family history, which was done door to door. The study sample was hyperuricemic patients aged over 30 years in Bangli General Hospital which was selected by simple random sampling.

\subsection{Ethical Consideration}

The study, the collection of clinical and epidemiological data submitted for ethical approval to the Research Ethic Committee of Universitas Udayana, Denpasar. Enrolment of the study participants is conditional on appropriate consent.

\section{Results And Discussion}

The results of the study of the relationship between obesity and family history with uric acid levels in patients with hyperuricemia aged over 30 years in Bangli general hospital on 77 selected respondents were presented in the form of univariate analysis for the distribution of sample characteristics and bivariate analysis to determine the relationship of each variable

Table 1. Characteristics of Respondents $(n=77)$

\begin{tabular}{ll}
\hline Variable & Frequency $(\%)$ \\
\hline
\end{tabular}




\begin{tabular}{cc}
\hline \multicolumn{1}{c}{ Variable } & Frequency (\%) \\
\hline Gender & \\
\hline Male & $34(44.2)$ \\
Female & $43(55.8)$ \\
Age (Years) & $19(24.7)$ \\
$31-40$ & $17(22.1)$ \\
$41-50$ & $24(31.2)$ \\
$51-60$ & $17(22.1)$ \\
$>60$ & \\
Recent Education & $10(13.0)$ \\
Non elementary graduate & $19(24.7)$ \\
Elementary school & $17(22.1)$ \\
Junior high school & $11(14.3)$ \\
Senior high school & $20(26.0)$ \\
University & \\
Housewife & $23(29.9)$ \\
Civil servant & $11(14.3)$ \\
Private employee & $9(11.7)$ \\
Entrepreneur & $17(22.1)$ \\
Laborer & $10(13.0)$ \\
Others & $7(9.1)$ \\
\hline
\end{tabular}

As shown in the data in Table 1, most of the respondents are women with a frequency of 43 respondents $(55.8 \%)$. Most respondents were 51-60 years old, 24 respondents $(31.2 \%)$. The highest number of respondents have the background of university education, accounted for 20 respondents $(26.0 \%)$. Most respondents were housewives, amounted to 23 respondents $(29.9 \%)$.

Table 2. Obesity Incidence, Blood Uric Acid Levels, Family History $(\mathrm{n}=77)$

\begin{tabular}{lc}
\hline \multicolumn{1}{c}{ Variable } & Frequency (\%) \\
\hline Obesity & $49(63.3)$ \\
Yes & $28(36.4)$ \\
No & \\
\hline Uric Acid Level & $49(63.3)$ \\
Above normal & $28(36.4)$ \\
Normal & \\
\hline Family History & $46(59.7)$ \\
Present & $31(40.3)$ \\
Absent & \\
\hline
\end{tabular}

Table 2 shows more respondents have obesity as many as 49 respondents $(63.6 \%)$. More respondents have blood uric acid levels above normal amounted to 49 respondents $(63.6 \%)$ and more respondents have a positive family history of 46 respondents $(59.7 \%)$

Table 3. Relationship between Obesity and Blood Uric Acid Levels $(n=77)$

\begin{tabular}{lllll}
\hline \multirow{2}{*}{ Variable } & \multicolumn{2}{c}{ Uric Acid Level } & \multirow{2}{*}{ Total } & $P$ \\
\cline { 2 - 2 } & Above Normal (\%) & Normal (\%) & \\
\hline
\end{tabular}




\begin{tabular}{lcccc}
\hline \multirow{2}{*}{ Variable } & \multicolumn{2}{c}{ Uric Acid Level } & \multirow{2}{*}{ Total } & \multirow{2}{*}{$P$} \\
\cline { 2 - 3 } Obesity & Above Normal (\%) & Normal (\%) & & \\
Yes & $35(71.4)$ & $(28.6)$ & 49 & 0.060 \\
No & $14(50.0)$ & $14(50.0)$ & 31 & \\
\hline Total & $39(63.6)$ & $43(36.4)$ & 77 & \\
\hline
\end{tabular}

Table 3 shows that 35 respondents $(71.4 \%)$ who are obese have blood uric acid levels above normal and as many as 14 respondents $(28.6 \%)$ who are obese have normal blood uric acid levels. While as many as 14 respondents $(50.0 \%)$ who are not obese have blood uric acid levels above normal and 14 respondents $(50.0 \%)$ who are not obese have normal blood uric acid levels. Based on the results of the bivariate test with chi-square found the $p$ value $=0.060$ $(p>\alpha)$ shows that there is no relationship between obesity and blood uric acid levels

Table 4 Relationship between Family History and Blood Uric Acid Levels ( $\mathrm{n}=77)$

\begin{tabular}{lcccc}
\hline \multirow{2}{*}{ Variable } & \multicolumn{2}{c}{ Uric Acid Level } & \multirow{2}{*}{ Total } & \multirow{2}{*}{$\boldsymbol{P}$} \\
\hline Family History & Above Normal (\%) & Normal (\%) & & \multirow{2}{*}{0.006} \\
Yes & $35(76.1)$ & $11(23.9)$ & 46 & \\
No & $14(45.2)$ & $17(15.8)$ & 31 & \\
\hline Total & $49(63.6)$ & $28(36.4)$ & 7 & \\
\hline
\end{tabular}

Table 4 shows that 35 respondents $(76.1 \%)$ have the family history of suffering from blood uric acid levels that are above normal and as many as 11 respondents $(23.9 \%)$ with a family history of normal blood uric acid levels. While as many as 14 respondents $(45.2 \%)$ who have no family history have blood uric acid levels above normal and as many as 17 respondents $(54.8 \%)$ with no family history have normal blood uric acid levels. Based on the results of the bivariate test with chi-square, the $\mathrm{p}$ value $=0.006(\mathrm{p}<\alpha)$ showed that there is a relationship between family history and blood uric acid levels.

In this study, the majority of respondents are female $(55.8 \%)$. The results of this study are in line with the research conducted by Oktaviana (2015) on the relationship of nutritional status with gout arthritis in the elderly at Wawonasa Manado Public Health Center, where the sample distribution based on sex of the majority of respondents is female (75.0\%).[7] The study conducted by Tyas (2009) on the relationship of body mass index with blood uric acid levels in the population of Banjaranyar Village, Sokaraja Subdistrict, Banyumas Regency, found the same results, where the majority of respondents are female (59.6\%).[8] Research conducted by Husnah and Dewi (2013) on the relationship between community awareness related to purine diet and uric acid levels in patients with gout arthritis, also showed the same results, where $55.8 \%$ are female. [9]

Based on the age category, the majority of respondents are 51-60 years old (31.2\%). This research is in line with the research conducted by Husnah and Dewi (2013) about the relationship between knowledge of purine diet and uric acid levels in gout arthritis patients, obtained (61.5\%) of respondents aged 40-60 years.9 Andry (2009) also conducted a study of the analysis of factors affecting uric acid levels in office workers in Karang Turi Village, Bumiayu District, Brebes Regency, found out that $52 \%$ respondents aged $\geq 50$ years. [10]

Based on the education background, the respondents are divided into 5 categories; not graduating from elementary, elementary, junior high school, senior high school and university where the highest number of respondents are university graduates $(26.0 \%)$. This research is in 
line with the research conducted by Linda (2014) about the relationship between protein intake and family history with uric acid levels in lecturer staff and employees of the Public Health Faculty of Sam Ratulagi University in Manado, obtained that $68.9 \%$ of respondents are university graduates. [11] The results of this study are not in line with the research conducted by Hana (2015) regarding the relationship of nutritional status, food intake of sources of purines with uric acid levels in outpatient hyperurisemic patients at Tugurejo Hospital Semarang, obtained $36.4 \%$ of respondents are junior high school graduates. [12]

Based on the occupation, respondents are divided into 6 categories; housewives, civil servants, private employees, entrepreneurs, laborers and others with the most respondents are housewives $(29.9 \%)$. This research is in line with the research conducted by Evi Lestari (2012) on the relationship of purine-containing foods consumption with uric acid levels in women aged 45-59 years in Sanggrahan Village, Kranggan District, Temanggung Regency, where $64.8 \%$ respondents worked as housewives. [13] The results of this study are not in line with the research conducted by Petri (2011) on the effect of gout arthritis health education on gout arthritis prevention behavior in the elderly at Kedungtangkil Posyandu Karangsari Pengasih Kulon Progo Yogyakarta, showed 83.3\% respondents worked as farmers. [14]

Based on the uric acid level, the respondents were divided into 2 categories; normal and above normal. More respondents were found to have blood uric acid levels above normal $(63.6 \%)$. This research is in line with the research conducted by Hana (2014) about the relationship of nutritional status, purin-containing food consumption with uric acid levels in outpatient hyperuresemia patients at Tugurejo Hospital Semarang, showing that $72.7 \%$ respondents had the above uric acid levels normal. [12] The study conducted by Husnah and Dewi (2013) on the relationship of knowledge of purine diet with uric acid levels in patients with gout arthritis, showed (75\%) respondents had high uric acid levels. [9]

Respondents' obesity was divided into 2 categories of yes and no, where most of the respondents had obesity $(63.6 \%)$. The results of this study are different from the research conducted by Setyo (2014) about the factors that affect uric acid levels (gout) in adult men at RT 04 RW 03 Simomulyo Baru Surabaya, indicating 85.0\% respondents were not obese. [2] Research conducted by Tyas (2009) on the relationship of body mass index with blood uric acid levels in the residents of Banjaranyar Village, Sokaraja Subdistrict, Banyumas Regency showed different results, where the BMI average value was $24.38 \mathrm{~kg} / \mathrm{m} 2$, so the average BMI of the population is not obese. [8]

The family history of the respondents was divided into 2 categories, there are positive and negative family history, where more respondents had a family history of hyperuricemia $(59.7 \%)$. This research is in line with the research conducted by Linda (2014) about the relationship between protein intake and family history with uric acid levels in lecturer staff and employees of the Public Health Faculty of Sam Ratulagi University in Manado, where $55.6 \%$ respondents had a family history of hyperuricemia. 11 This study is also in line with the research conducted by Cindy (2015) about the relationship between family history and alcohol consumption with blood uric acid levels in patients who came to visit Paniki Bawah Health Center, Mapanget District, Manado City, showing that $57.0 \%$ respondents had a familial history of hyperuricemia. [5]

In this study it was found the $p$ value $=0.060(p>\alpha)$ showed that there was no relationship between obesity and blood uric acid levels. The same results were also found in a study conducted by Tyas (2009) regarding the relationship of body mass index with blood uric acid levels in the population of Banjaranyar Village, Sokaraja Subdistrict, Banyumas Regency women and $\mathrm{p}$ value $=0.070(\mathrm{p}>\alpha)$ in male respondents which showed that there was no significant relationship between BMI and uric acid levels. [8] This is probably due to the fact 
that the sample from this study differs from previous studies and may be caused by the confounding factors which led to different results of this study. [15]

In this study $\mathrm{p}=0.006(\mathrm{p}<\alpha)$ showed that there was a relationship between family history and blood uric acid levels. The research conducted by Sukarmin (2015) about the factors related to uric acid levels in the gout patients in Kedungwinong Village, Sukolilo Pati showed similar results with this study. Based on the statistical test, the value of $p=0.03(p<\alpha)$ showed that there was a significant relationship between family history and uric acid level. [16] Research with the similar results was also carried out by Cindy (2015) about the relationship between family history and alcohol consumption with blood uric acid levels in patients who came to visit the Paniki Bawah Health Center in Mapanget District, Manado City. Based on the statistical test, the value of $p=0,000(p<\alpha)$ showed that there was a significant relationship between family history and uric acid level. [5]

Based on the theory, it is explained that people with a family history of hyperuricemia have a 1-2-fold risk compared to patients with no familial history. [17] In addition, the analysis of The National Heart, Lung, and Blood Institute Family Studies shows the relationship between hereditary history and the level of uric acid amounted to 40\%.[2]

\section{Conclusions}

Most of the samples are women (55.8\%). The age of the majority of respondents is 51-60 years old $(31.2 \%)$. The highest number of respondents are university graduates $(26.0 \%)$. Most of the respondents are housewives (29.9\%). The results of the BMI measurement indicated that more respondents had obesity as many as 49 respondents $(63.6 \%)$. Most respondents have a family history with high uric acid level of 46 respondents (59.7\%). As many as $63.6 \%$ of the respondents have blood uric acid levels above the normal. There is no significant relationship between BMI and uric acid levels.

There is a significant relationship between family history and blood uric acid levels.

\section{References}

[1] Rau, E., O. J, K. V. (2015). Perbandingan Kadar Asam Urat Pada Subyek Obes dan Non-Obes di Fakultas Kedokteran Universitas Sam Ratulangi Manado. Jurnal E-CliniC (ECL): 3(2).

[2] Astuti, S. T. W., \& Tjahjono, H. D. (2014). Faktor-Faktor Yang Memengaruhi Kadar Asam Urat (Gout) Pada Laki-Laki Dewasa Di RT 04 RW 03 Simomulyo Baru Surabaya. Jurnal S1 Keperawatan: 3(2).

[3] Kementerian Kesehatan, R. (2013). Laporan Hasil Riset Kesehatan Dasar (Riskesdas) 2013, Jakarta: Kementerian Kesehatan RIDinKes Jateng.

[4] Lizawati, L., \& Prabowo, T. (2014). Hubungan Indeks Massa Tubuh dengan Hiperurisemia pada Usia Dewasa di Dusun Daleman Gadingharjo Sanden Bantul [skripsi tesis]. Yogyakarta (Indonesia): STIKES Aisyiyah.

[5] Bangunang, C. C., K. GH. M, J. WB. S. (2015). Hubungan Antara Riwayat Keluarga dan Konsumsi Alkohol Dengan Kadar Asam Urat Darah Pada Pasien Yang Datang Berkunjung di Puskesmas Paniki Bawah Kecamatan Mapanget Kota Manado [skripsi].

[6] Wisesa, I. B. N., \& Suastika, K. (2009). Hubungan Antara Konsentrasi Asam Urat Serum Dengan Resistensi Insulin Pada Penduduk Suku Bali Asli Di Dusun Tenganan Pegringsingan Karangasem. Jurnal Penyakit Dalam: 10(2): 110-112. 
[7] Lumunon, O. J., B. H, H. R. (2015). Hubungan Status Gizi Dengan Gout Arthritis Pada Lanjut Usia Di Puskesmas Wawonasa Manado. Jurnal Keperawatan 3(3).

[8] Kumalasari, T. S., S, P. I, (2009). Hubungan Indeks Massa Tubuh dengan Kadar Asam Urat Darah pada Penduduk Desa Banjaranyar Kecamatan Sokaraja Kabupaten Banyumas. Jurnal Keperawatan Soedirman (JKS) 4(3): 119-124.

[9] Husnah, H., \& Rahmatika, D. C. (2013). Hubungan Pengetahuan Diet Purin Dengan Kadar Asam Urat Pasien Gout Arthritis. Jurnal Kedokteran Syiah Kuala, 13(1), 13-17.

[10] Tahta, A., S. U, A. S. (2009). Analisis Faktor-Faktor yang Mempengaruhi Kadar Asam Urat pada Pekerja Kantor di Desa Karang Turi, Kecamatan Bumiayu, Kabupaten Brebes. Jurnal Keperawatan Soedirman, 4(1), 25-31.

[11]Landeeo, L. R., M. N, R. A. J. M. (2014). Hubungan Antara Asupan Protein Dan Riwayat Keluarga Dengan Kadar Asam Urat Pada Staf Dosen Dan Pegawai Fakultas Kesehatan Masyarakat Universitas Sam Ratulagi Manado. [Skripsi].

[12] [Silviana, H., B. S, I. J. T. (2015). Hubungan Status Gizi, Asupan Bahan Makan Sumber Purin dengan Kadar Asam Urat pada Pasien Hiperuresemia Rawat Jalan di Rumah Sakit Tugurejo Semarang. Jurnal Gizi. 4(2).

[13] Lestari, E., M. S, P. M. D (2012). Hubungan Konsumsi Makanan Sumber Purin Dengan Kadar Asam Urat Pada Wanita Usia 45-59 Tahun Di Desa Sanggrahan Kecamatan Kranggan Kabupaten Temanggung. [Skripsi].

[14] Kurniawan, P., \& Isnaeni, Y. (2011) Pengaruh Pendidikan Kesehatan Arthritis Gout terhadap Perilaku Pencegahan Arthritis Gout pada Lansia di Posyandu Kedungtangkil Karangsari Pengasih Kulon Progo Yogyakarta. [Skripsi thesis]. Yogyakarta (Indonesia): STIKES Aisyiyah.

[15]Febby, Y. (2013). Hubungan Indeks Masa Tubuh Dan Usia Dengan Kadar Asam Urat Pada Remaja Pra-Obes Dan Obes Di Purwokerto. [Skripsi].

[16] Sukarmin, S. (2015). Faktor-Faktor yang Berhubungan dengan Kadar Asam Urat Dalam Darah Pasien Gout di Desa Kedungwinong Sukolilo Pati. [skripsi]

[17] Purwaningsih, T. (2010). Faktor-Faktor Risiko Hiperurisemia (Studi Kasus Di Rumah Sakit Umum Kardinah Kota Tegal). [Thesis]. Universitas Diponegoro.Permendikbud No 65 Tahun 2013 Tentang Standar Proses Pendidikan Dasar dan Menengah Jakarta: Depdiknas 